\title{
Climate Change Perception and Farmers' Adoption of Sustainable Land Management for Robust Adaptation in Cameroon
}

\author{
Ernest L. Molua ${ }^{1}$ \\ ${ }^{1}$ Department of Agricultural Economics and Agribusiness, Faculty of Agriculture \& Veterinary Medicine, \\ University of Buea, Buea, Cameroon \\ Correspondence: Ernest L. Molua, Department of Agricultural Economics and Agribusiness, Faculty of \\ Agriculture \& Veterinary Medicine, University of Buea, P.O. Box 63 Buea, Cameroon. Tel: 237-9949-4393. Fax: \\ 237-3332-2272. E-mail: emolua@cidrcam.org
}

\author{
Received: June 27, 2014 Accepted: October 21, 2014 Online Published: November 15, 2014 \\ doi:10.5539/jas.v6n12p202 URL: http://dx.doi.org/10.5539/jas.v6n12p202
}

\begin{abstract}
The certainty of a changing climate is asserted in the perception of observable changes in rainfall and temperature reported by more than $52 \%$ of farm managers in Cameroon's dry North region and almost $70 \%$ in the humid West region. Responding to these observable changes, soil and crop management techniques are adopted to ease climatic stress and insure farms from income shocks and associated vulnerabilities. Farmers were surveyed on their participation in sustainable land management (SLM) programs, and a probit model reveals that the probability of adopting recommended SLM techniques is influenced by land tenure, education, gender, experience and non-farm income. Noting that producers' adoption of recommended SLM measures is the initial step for medium to long-term adaptation of the productive capacity of their farmland, the Switching Regression Model shows that property rights, access to market, access to extension and adaptation due to farmers' perception of a changing climate significantly contribute to income security. While this is informative for policy measures required to promote technology adoption, however, participating and employing SLM is a plausible insurance to both current climate variability and long-term climate change.
\end{abstract}

Keywords: climate change, sustainable land management, adoption, adaptation, farm income, Cameroon

\section{Introduction}

Climate change exacerbates the perennial challenges facing food, agriculture and rural development in developing countries. For vulnerable poor and food insecure people, the prospect of rising inequality is worsened by climate change (FAO, 2009). According to the Millennium Ecosystem Assessment (2005), knowledge-based procedures which integrate land and environmental management are critical to meet rising food and fibre demands while sustaining ecosystem services and livelihoods. Improper land management leads to land degradation and a significant reduction in the productive and service functions of landscapes. However, preserving and enhancing the productive capabilities of land in cropped, forested or grazed area and employing actions to stop, reverse or mitigate degradation is necessary to address the requirements for vulnerable food insecure communities.

With the associated risks of climate change, Müller et al. (2011) notes that agricultural production, including access to food may be severely compromised. For example, climate change impacts agricultural water supply and soil nutrient wealth. Farmland and soil health depend on microclimates which are in turn influenced by regional and global climate change (IPCC, 2007). Such challenges require serious, immediate and sustained investments in farmland productivity. According to Schlenker and Lobell (2010) this would include improved irrigation systems, rainwater harvesting and drought and heat tolerant varieties. This, however, raises important questions on localized impact, e.g. to what extent can good land management contribute to sustaining a high level of agricultural productivity?

In Cameroon, traditional agricultural practices which exacerbate land degradation, particularly through soil erosion, have negative impacts on farm productivity and environmental quality (Adesina et al., 2000; Jaza Folefack, 2008). The outcome is threatened by severe social, environmental and economic consequences such as decreased smallholder farmland productivity and falling rural incomes (Jaza Folefack, 2008). Robust negative impacts of climate variation and climate change have been shown to be contemporaneous constraints to African 
agriculture (Müller et al., 2011; Roudier, 2011; Schlenker \& Lobell, 2010). For instance, Roudier (2011) notes from a meta-database of future crop yields, built up from sixteen studies on West Africa's rainfed agriculture, that despite a large dispersion of yield changes ranging from $-50 \%$ to $+90 \%$, the median is a yield loss near $-11 \%$, with the predicted impact larger in northern West Africa (Sudano-Sahelian countries: $-18 \%$ median response) than in southern West Africa (Guinean countries: -13\%). In the advent of climate change, achieving agricultural productivity growth will require developing and disseminating land management technologies (Hurni, 2000). The immediate effects of climate variability and the perceptions of long-term climate change may reinforce the impact on farm productivity and profitability (Molua et al., 2010). For instance, Bryant et al. (2000), Maddison (2006) and Gbetibouo (2009) note that the perceptions of climate change influence farming decisions. While the agricultural decisions are wide and varied, they could however be grouped into soil management choices, crop management choices and socioeconomic choices (Molua, 2011; Kurukulasuriya \& Mendelsohn, 2008). Despite these challenges, improving the productivity, profitability and sustainability of such smallholder farming is an important pathway out of poverty (Kassie et al., 2008; Holden et al., 2004). This paper therefore aims to measure and analyze the adoption of farmland conservation measures under climate change perception in Cameroon. This type of analysis is useful for policy decision-making because it facilitates the understanding of the circumstances under which promoting alternative land conservation technologies may have their greatest impacts.

\section{Materials and Methods}

\subsection{Data Generation and Sources}

In this study, we examine the performances of 103 farmers who are exposed to Sustainable Land Management (SLM) technology package through Cameroon's National Community driven Development Programme (PNDP) sustaining natural capital management programme (Note 1). Primary data is thus employed by surveying farms and households in the West and Northern regions of Cameroon. The programme has selected beneficiary farmers who are exposed to a package of SLM technologies. Both beneficiaries (i.e. PNDP programme contact-farmers who receive information and training on environment and ecosystem management.) and non-beneficiaries of the programme are sampled and studied, on the possibility of their adoptive behaviours of the principles of sustaining land management. The objective of the survey was to generate information on the choices farmers make to insure the resilience of the farmland, and to establish whether these choices are influenced by climate change perception and some socioeconomic parameters (e.g. income, age, gender, education, climate, soil type, etc.). One hundred and three (103) beneficiary farms and one hundred and twelve (112) non-beneficiary farms were studied in six communities in three regions, viz., North region (Fada, Gamba and Mayo Lebri), Adamawa region (Njoundé) and West region (Lagui and Kouptamo). The face-to-face interviews were administered in French in the three regions indicated in Figure 2. The information was collected with the use of questionnaire. Figure 3 depicts the climate disparity in the three regions studied. 


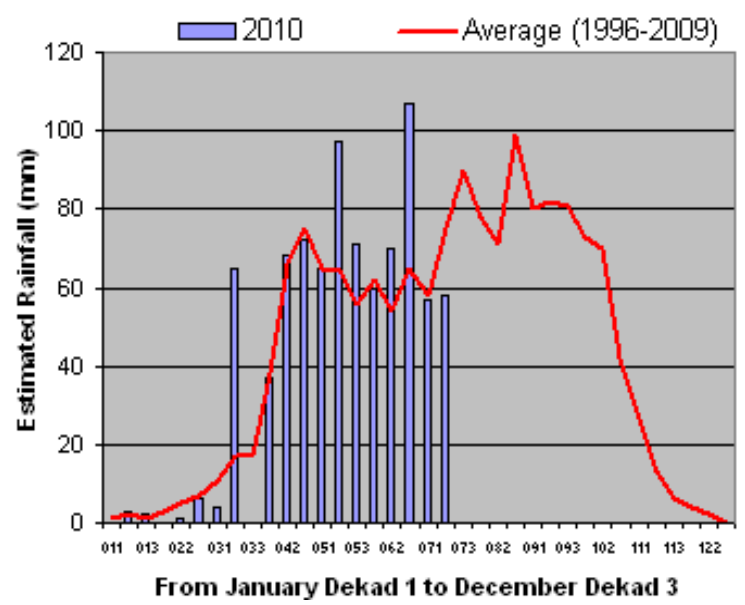

Adamawa

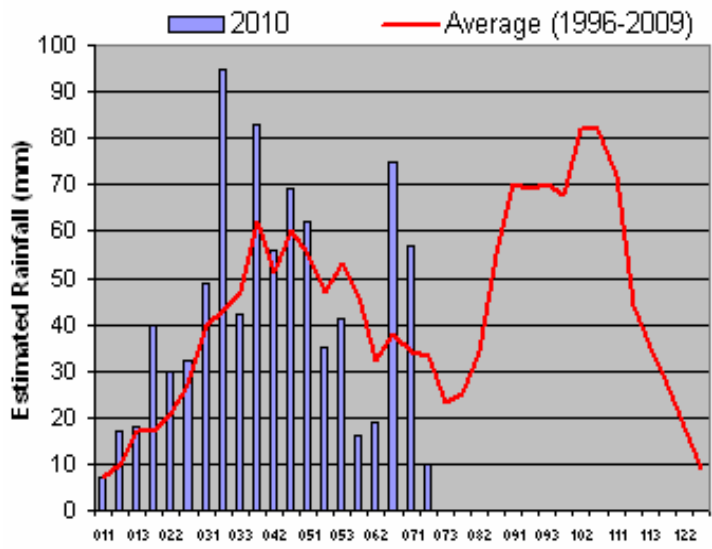

From January Dekad 1 to December Dekad 3

North Region

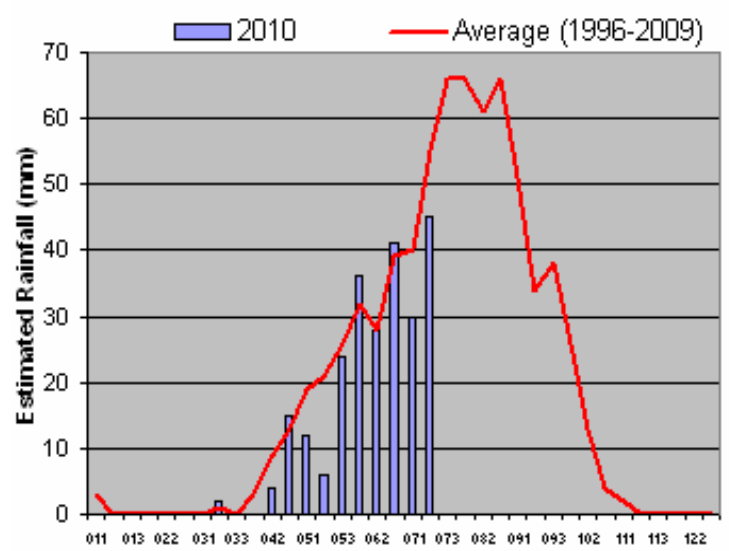

From January Dekad 1 to December Dekad 3

West Region

Figure 1. Interpolated estimated decadal distribution in the different regions of Cameroon Source: NOAA/FEWSNet; FAO/NRCB-Agrometeorology Group.

\subsection{Analytical Framework for Assessing Land Management Practices}

According to Pender et al. (2006), agricultural production and land conditions are affected by land management practices, including both private decisions made by farm households and collective decisions made by groups of farmers and communities. For instance, studies have shown that farming decisions that include farm managers employing soil bunds and terracing to control runoff and soil erosion produce higher yields (Benin, 2006; Pender \& Gebremedhin, 2006; Bekele, 2005). The economic returns on physical soil and water conservation investments, as well as their impacts on productivity have been shown to be positive and significant (Shively, 1998; Gebremedhin et al., 1999; Kassie et al., 2008). However, farmers in Cameroon, whether beneficiary of public schemes or not, experience the same set of socio-economic circumstances which requires them to still make a choice between investing on land management in a given season. Figure 2 shows that the techniques employed by different groups of farmers, whether indigenous or modern, could be evolutionary, improving farm output. However, it is expected that the gamut of practices and techniques employed by farmers in the medium-term becomes transformational into a path of adaptation until the technology becomes obsolete and land-users move either to a new set technology and or eventual change in land-use to insure for sustained profitable land value as noted in Mendelsohn et al. (1994).

The conceptualization in Figure 2 reveals that the initial stages of technology adoption is different for different groups of farmers, which however, later transforms into a particular adaptation path for a given technology, e.g. stone contour bunds. As climate changes, farms initially observe increasing returns as a factor of the technology 
selected, with a potential for decreasing marginal farm returns for the technology as climate changes further. There is an optimum farm and climate value beyond which a given technology becomes unfit to ensure positive farm returns. These declines in farm returns are experienced at different levels by different groups of technology adopters, and different kinds of adaptation with unexposed non-beneficiary farmers who may rely on indigenous low potential technology experiencing lower returns relative to innovators and farm groups that are exposed to a package of scientifically based and tested green-revolution technology such as the SLM package. To observe higher returns, farmers will either need to imitate, innovate or adopt recommended technology package, or face the risk of being squeezed into smaller profits. Making the transition from current levels to imitations and adoption will depend on the social, economic, political and environmental factors experienced by the farmers (see e.g. Nhemachena et al., 2010; Gbetibouo, 2009; Pender et al., 2006; Adesina et al., 2000; Shiferaw \& Holden, 1998; Adesina \& Baidu-Forson, 1995).

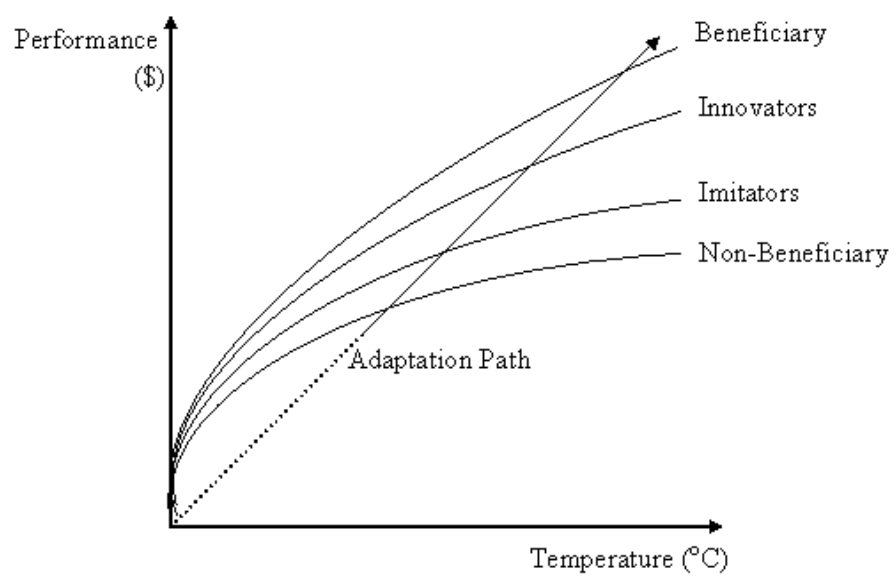

Figure 2. Technology Exposure and Adaptation Path

This implies that the decision to select from a repertoire of land management technologies, whether soil fertility based or crop management is not necessarily independent of that to select the other. The selection problem of farmers who chose a particular technology can be addressed by the application of a switching regression model with endogenous switching (Maddala, 1983). The level of adoption of farmland management can be described by a criterion function, which is postulated to be associated with exogenous household socioeconomic variables as follows:

$$
A_{i}=\delta Z_{i}+\mu_{0}
$$

Where $A$ is the level of adoption of the SLM technology package, subscript $i$ denotes farm-households, $Z$ is a vector of exogenous variables, $\delta$ are the unknown parameters and $\mu_{0}$ is the disturbance term. By dividing the sample in two subgroups (beneficiaries denoted ' $\mathrm{B}$ ' and non-beneficiaries denoted ' $\mathrm{N}$ ' of the SLM package), the dependent variable can be redefined as a dichotomous variable (i.e., $A=1$ for adopting beneficiaries and 0 for non-adopting non-beneficiaries) and the parameters in Equation (1) can then be estimated as a Probit model.

In the switching-regression approach as employed in Awudu and Binder (2006), separate equations may be specified for adopters and non-adopters of the prescribed SLM technology package in order to capture the differential response of the two groups. In the present analysis, such a specification takes the following form:

$$
\begin{array}{cc}
Y_{B}=\beta_{B} X_{B i}+\mu_{B} & \text { if } B=1 \\
Y_{N}=\beta_{N} X_{N i}+\mu_{N} & \text { if } N=0
\end{array}
$$

where $Y_{B}$ and $Y_{N}$ represent output for farms who are beneficiary and non-beneficiary of the PNDP SLM technology package, respectively. $X_{B}$ and $X_{N}$ are vectors of exogenous variables, $\beta_{B}$ and $\beta_{N}$ are unknown parameters, and $\mu_{B}$ and $\mu_{N}$ are random disturbance terms. The variable $Y_{B}$ is an outcome variable when the technology is adopted, and $Y_{N}$ represents the output without adoption. Given that the choice of technology is endogenous in the above specification, ordinary least square (OLS) estimates of the parameters in Equations (2) and (3) will suffer from sample selection bias. Thus, their error terms, conditional on the sample selection criterion, have non-zero expected values (Lee, 1982; Maddala, 1983). Hence, in order to obtain unbiased estimates it is necessary to estimate Equations (1), (2) and (3) simultaneously using maximum likelihood 
techniques. The estimation of this system of equations using maximum likelihood is feasible but complicated. To simplify the estimation, sample selectivity is treated as a missing-variable problem in Lee's (1982) approach. A joint-normal distribution is postulated for the error terms with the following variance-covariance structure

$$
\operatorname{Cov}\left(\mu_{B}, \mu_{N}, \mu_{0}\right)=\left[\begin{array}{ccc}
\sigma_{B}^{2} & \sigma_{B N} & \omega_{B 0} \\
\sigma_{B N} & \sigma_{N}^{2} & \sigma_{N 0} \\
\sigma_{B 0} & \sigma_{N 0} & \sigma^{2}
\end{array}\right]
$$

Where: $\sigma_{B}^{2}=\operatorname{var}\left(\mu_{B}\right), \sigma_{N}^{2}=\operatorname{var}\left(\mu_{N}\right), \sigma^{2}=\operatorname{var}\left(\mu_{0}\right), \sigma_{B N}=\operatorname{cov}\left(\mu_{B}, \mu_{N}\right), \sigma_{B 0}=\operatorname{cov}\left(\mu_{B}, \mu_{0}\right), \sigma_{N 0}=\operatorname{cov}\left(\mu_{N}, \mu_{0}\right)$

The conditional expectations of $\mu_{B}$ and $\mu_{N}$ are then given as (Johnson \& Kotz, 1970):

$$
\begin{gathered}
E\left(\mu_{B} \mid A=1\right)=E\left(\mu_{B} \mid \mu_{0}>-Z^{\prime} \delta\right)=\sigma_{B 0} \frac{\phi\left(Z^{\prime} \delta / \sigma\right)}{\Phi\left(Z^{\prime} \delta / \sigma\right)} \equiv \sigma_{B 0} W_{B} \\
E\left(\mu_{N} \mid A=0\right)=E\left(\mu_{A} \mid \mu_{0} \leq-Z^{\prime} \delta\right)=\sigma_{N 0} \frac{-\phi\left(Z^{\prime} \delta / \sigma\right)}{1-\Phi\left(Z^{\prime} \delta / \sigma\right)} \equiv \sigma_{N 0} W_{N}
\end{gathered}
$$

Where $\mathrm{Z}$ and $\delta$ are respectively, the vector of exogenous variables and the estimated parameters from Equation (1), and $\phi$ and $\Phi$ are the probability density and the cumulative distribution functions of the standard normal distribution, respectively. The ratio of $\phi_{\text {and }} \Phi$ evaluated at $Z^{\prime} \delta$ is referred to as the inverse Mills ratio (selectivity terms). The selectivity terms, $W_{B}$ and $W_{N}$, can be considered as missing variables in Equations (2) and (3). If suitable instruments can be found for these variables, they can be included in the specification given in Equations (2) and (3) to obtain consistent estimates with OLS.

Thus, the estimation proceeds in two stages. The first step involves a probit regression to determine the probability of adoption. The estimates are then used to estimate the selectivity terms $\mathrm{W}_{\mathrm{B}}$ and $\mathrm{W}_{\mathrm{N}}$ according to the definitions in Equations (5) and (6). The second stage of the estimation process incorporates the selectivity terms in the multiple regressions given in Equations (2) and (3), resulting in the following equations:

$$
\begin{array}{cc}
Y_{B}=\beta_{B} X^{\prime}+\sigma_{B 0} W_{B}+\mu_{B} & \text { if } A=1 \\
Y_{N}=\beta_{N} X^{\prime}+\sigma_{N 0} W_{N}+\mu_{N} & \text { if } A=0
\end{array}
$$

These equations are then estimated by OLS. The coefficients of the variables $W_{B}$ and $W_{N}$ provide estimates of the covariance terms $\sigma_{B 0}$ and $\sigma_{N 0}$, respectively. In particular, if the covariance terms are nonzero, then OLS estimates of Equations (2) and (3) would be biased as a result of sample selection. Freeman et al. (1998) show that new residuals $\mu_{B}$ and $\mu_{N}$ have conditional means of zero but are heteroscedastic and they suggest estimating Equations (7) and (8) by weighted least square (WLS) to obtain efficient parameters.

In the current study, the signs of the coefficients of the selectivity terms $\left(W_{B}\right.$ and $\left.W_{N}\right)$ have an economic interpretation. If they have alternate signs, then farmers practice the SLM technology package on the basis of their comparative advantage. Thus, those who are beneficiaries of the programme and adopt it have above-average returns from adoption, while the non-beneficiaries who do not adopt it have above-average returns from non-adoption. On the other hand, if the coefficients of the selectivity terms have the same sign, it indicates hierarchical sorting; that is, the beneficiary adopters have above-average returns whether they adopt or not, but they are better-off adopting than not adopting. The non-beneficiary non-adopters have below-average returns in either case, but are better-off not adopting (see Willis \& Rosen, 1979).

\section{Results and Discussion}

\subsection{Farm Types, Practices and Crop Patterns}

Table 1 lists the access to farming plots and grazing land in the six municipalities within the three regions examined in the current study. The table highlights the diverse patterns employed by households and farm managers. Households have on average access to a crop plot, with some households having a maximum of 5 plots. Access to individual grazing plots is limited, as livestock is principally grazed on communal lands. The crop plots provide on average 3 different commodities to the households averaging in size of 7 members reaching a maximum of 23 persons. The challenge to ensure better returns to farms and cater for the food and income security of households rests on household heads who are typically 45 years in age with about 12 years of farming experience, though these may reach 90 and 50 years, respectively. In general, as shown in Table 1 there is little difference on the biographic profile between households that are beneficiaries or not of the PNDP natural resource management capacity programme. 
Table 1. Crop plots and grazing land access

\begin{tabular}{|c|c|c|c|c|c|c|c|c|}
\hline \multirow{2}{*}{ Parameters } & \multicolumn{4}{|c|}{ Beneficiaries } & \multicolumn{4}{|c|}{ Non-Beneficiaries } \\
\hline & Mean & Min & Max & Stand dev & Mean & Min & Max & Stand dev \\
\hline Crop plots (no.) & 1.48 & 0 & 5 & 0.84 & 1.37 & 0 & 4 & 0.73 \\
\hline Grazing plots (no.) & 0.2 & 0 & 3 & 0.40 & 0.21 & 0 & 9 & 0.41 \\
\hline Agric Products (no.) & 3.24 & 0 & 10 & 1.68 & 5.28 & 0 & 13 & 1.48 \\
\hline Livestock Products (no.) & 0.38 & 0 & 3 & 0.82 & 0.58 & 0 & 6 & 1.23 \\
\hline Farms per household (no.) & 1.48 & 0 & 5 & 0.84 & 1.37 & 0 & 4 & 0.74 \\
\hline Grazing land exploited (ha) & 1.2 & 0.5 & 4 & 0.80 & 0.8 & 0.3 & 1.8 & 0.32 \\
\hline Household production unit (no.) & 2.68 & 1 & 5 & 0.83 & 1.59 & 1 & 4 & 0.79 \\
\hline Household size (no.) & 7.74 & 1 & 23 & 3.67 & 6.37 & 1 & 20 & 2.71 \\
\hline Farming Experience (Years) & 12.55 & 0 & 50 & 10.36 & 14.48 & 0 & 50 & 10.12 \\
\hline Age (years) & 45.26 & 13 & 90 & 13.69 & 49.96 & 18 & 78 & 14.07 \\
\hline
\end{tabular}

Source: computed from survey data, 2010.

\subsection{Agricultural Income and Enterprise Strategies with Climate Change Perception}

Farm revenue comes from agriculture (e.g. subsistence food production and marketing, cash crop production), livestock production, sale of forest products and non farm activities. Crop agriculture contributes the largest proportion to household income (71\%) followed by livestock production (14.9\%). Table 2 reveals that remittance and transfers from both domestic and international sources are also important accounting for $5 \%$ and $6.5 \%$ for beneficiary and non-beneficiaries, respectively. Revenue from forest products and wages earned from paid employment (e.g. off-farm labour) are equally important. More important is the $26 \%$ contribution from other sources such as non-farm production and non-agriculture enterprises, which include petty-trading, food marketing, mobile-telephony services, weaving, art and crafts production, etc.

Table 2. Sources of household revenue

\begin{tabular}{lccccc}
\hline & \multicolumn{2}{c}{ Beneficiaries } & & \multicolumn{2}{c}{ Non-Beneficiaries } \\
\cline { 2 - 3 } \cline { 5 - 6 } & Frequency & $\%$ & & Frequency & $\%$ \\
\hline Crop agriculture & 96 & 71.6 & & 96 & 77.4 \\
Livestock production & 20 & 14.9 & & 22 & 17.7 \\
Forest (wood products) & 2 & 1.5 & & 2 & 1.6 \\
Forest (non-wood products) & 2 & 1.5 & & 0 & 0 \\
Paid employment (wages) & 2 & 1.5 & & 4 & 3.2 \\
Remittance & 7 & 5.2 & & 8 & 6.5 \\
Credit & 5 & 3.7 & & 5 & 4.1 \\
Others (e.g. non-farm cottage enterprises) & 29 & 21.6 & & 41 & 32.8 \\
\hline
\end{tabular}

Source: computed from survey data, 2010.

A breakdown of farm revenues after employing the recommended techniques of sustainable soil and crop production reveal that farms for the beneficiaries of the capacity building programmes of the PNDP recoup the highest profits, as it is the case in Gamba (North region) (see Figure 3). Similarly, beneficiaries in Fada and Mayo Lebri (North region) experience better returns than beneficiaries in Ndjounde (Adamawa region) or Kouptamo (west region). However, comparing with non-beneficiaries, as shown in Figure 4, farmers in Ndjounde and Fada not exposed to the SNC capacity enhancing initiatives obtain higher values for their farm enterprise. While decisions regarding adaptation to temperature could be grouped either as crop, soil or socio-cultural measures, the individual responses highlight the importance of irrigation infrastructure, choice of 
crops, management techniques requiring less water, minimum tillage techniques and changing field design to increase ground cover. For grazing land, more trees are planted to provide shade for the animals, re-designing of animal housing, harvesting rainwater for drinking during dry season and use of fodder banks.

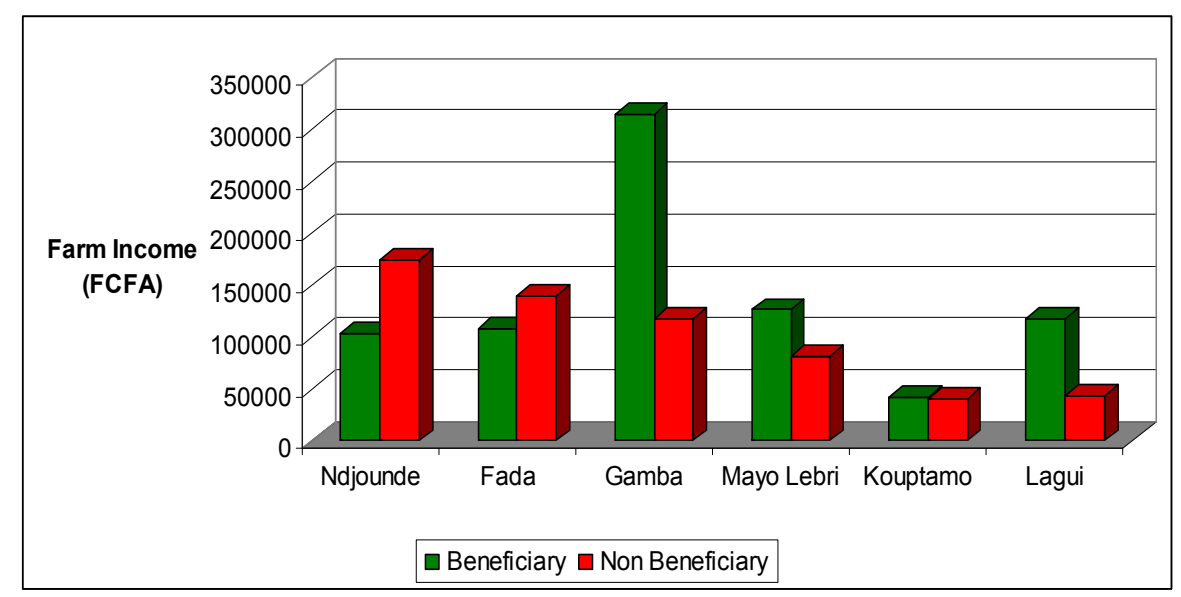

Figure 3. Farm income of SNC beneficiary and non-beneficiary households

Under the PNDP Programme (Exchange rate: $1 \mathrm{US} \$=500$ FCFA).

\subsection{Effects of Adoption on Farm Incomes under Climate Change Perception}

\subsubsection{Probit Model for Sustainable Land Management Technology Adoption}

The maximum likelihood estimates of the probit model for SLM technology adoption are reported in Table 3. The table shows the estimated coefficients along with their respective marginal effects (MEs). The MEs measure the change in the probability of adoption given a one-unit change in the explanatory variable. The MEs for the dummy and continuous variables are measured at the mean value of the regressors. In the evaluations, education and access to extension are positive and significant parameters thus indicating that human capital formation, through formal education, agricultural training and technical assistance, are essential in helping farmers to better understand the attributes of new technologies. Higher level of education has been hypothesized and proven to increase the probability of adopting new technologies (Gbetibouo, 2009; Adesina \& Baidu-Forson, 1995). Similarly, tenure or farmland ownership displays a positive and significant effect on the level of adoption of SLM. Specifically, households who own at least some of the land they farm are 31\% more likely to adopt SLM practices than those who do not. This corroborates Lutz et al. (1994) and Shultz et al. (1997) assertion that land ownership is likely to influence adoption.

The positive and significant effect of climate change perceived either as change in rainfall or change in temperature indicates that those producers who express awareness of climate change have a higher probability of investing in SLM practices than those who are unaware of the impending challenge. This implies that climate change awareness is an important pre-condition for adopting SLM technologies. This is plausible given the positive and significant influence of farming experience measured as number of years involved in farming activities. Hassan and Nhemachena (2007) show that farming experience increases the probability of adoption of measures to improve farm profit because experienced farmers have better knowledge and information on changes in climatic conditions and crop and livestock management practices. On average, about $70 \%$ of farmers across the study locations believe that the climate has changed. This perception is consistent with results reported from surveys conducted at other locations in Africa (Bryan, 2009; Mertz et al., 2009; Nyong et al., 2007; Sleggers, 2008; Thomas et al., 2007). 
Table 3. Probit model for sustainable land management technology adoption

\begin{tabular}{lccc}
\hline & Coefficients & $t$-values & Marginal effects \\
\hline Constant & 0.512 & 0.639 & \\
Temperature change perception & 0.092 & $1.828^{*}$ & 0.005 \\
Rainfall change perception & 0.054 & $1.932^{*}$ & 0.016 \\
Non-farm income & 0.214 & $2.365^{* *}$ & 0.023 \\
Farming Experience & 0.212 & $1.871^{* *}$ & 0.214 \\
Household size & 0.082 & 1.363 & 0.001 \\
Gender & 0.169 & $1.722^{*}$ & 0.001 \\
Education & 0.235 & $1.831^{*}$ & 0.032 \\
Tenure & 0.314 & $1.778^{*}$ & 0.125 \\
Production Area & -0.259 & $-2.059^{* *}$ & -0.029 \\
Market access & 0.328 & $1.627^{*}$ & 0.031 \\
North region & 0.168 & $2.239^{* * *}$ & 0.005 \\
West region & 0.107 & $1.822^{* *}$ & 0.001 \\
Adamawa region & 0.154 & $1.623^{*}$ & 0.003 \\
Livestock-only dependence & -0.036 & -1.234 & -0.001 \\
Forest-only dependence & -0.074 & -1.076 & -0.001 \\
Mixed farm (Agroforestry) & 0.382 & $2.309^{* *}$ & 0.145 \\
Access to Extension Service & 0.352 & $1.891^{* *}$ & 0.019 \\
\hline McFadden R ${ }^{2}$ & & & 0.392 \\
Log likelihood & & & -293.72 \\
Correct predictions & & & $75.36 \%$ \\
\hline
\end{tabular}

Note: The dependent dichotomous variable reflects the participation in the SLM programme. T-statistic followed by $*, * *$ and $* * *$ indicate significance at the $10 \%, 5 \%$ and $1 \%$ level, respectively. As is shown in Table 3 , the model correctly predicts farmers' decision to adopt soil conservation practices for $75 \%$ of the observations and the likelihood ratio test rejects the null hypothesis that all slope coefficients are equal to zero at the $5 \%$ level.

Production area or land size presents a negative and significant parameter, revealing an inverse relationship between the probability of investing in soil conservation and total area cultivated. However, farmers who had land rights or land titles had a higher probability of adopting the technology. Household size and investment in single enterprises such as livestock or forest exploitation do not appear to significantly influence the pattern of adoption of SLM. However, having access to non-farm income was significantly correlated with adoption, implying that farmers who earn additional income from non-farm sources are more likely to practice SLM. This confirms Sleggers (2008) and Thomas et al. (2007) observation that farmers' perception and response to rainfall needs are correlated with farming decisions and significant in determining farm outcomes.

The dummy variables for the geographic regions of the North, Adamawa and West regions capture the spatial and regional effects. All three regions present positive parameters, with two out of the three being statistically significant. More important, Agroforestry which is either a mix of arable field crops with perennial tree plants and or livestock rearing is strongly significant in promoting adoption of land management practices to ensure resilience of the farm enterprise. These results suggest that farmers in the North and Adamawa regions are more likely to adopt Agroforestry practices as more conservative measures to protect soil health and wealth. A possible explanation for this result might be the perception of the farmers in the different regions on the risks of a changing climate and environmental change. These findings complement the observations in Nhemachena et al. (2010), Wang et al. (2010) and Mertz et al. (2009) who note diverse farm making decisions in response to seasonal and regional variations. For instance, Nhemachena et al. (2010) notes small-scale mixed crop and livestock system is the most tolerant whereas specialized crop production is the most vulnerable to warming and 
lower rainfall.

\subsubsection{Farm Income Contingent on Sustainable Land Management}

Table 4 presents the switching regression estimates for farm return contingent on the effect of practicing SLM. The Beneficiary and Non-Beneficiary farms on SLM technology package are analysed, with the models incorporating the self-selectivity variables $W_{B}$ and $W_{N}$ generated in the first-stage analysis. If there is no selectivity bias then the parameters associated with $W_{B}$ and $W_{N}$ would not be statistically different from zero and direct estimation of the production model for each group would be adequate (Freeman et al., 1998). The parameters for the self-selectivity variables $W_{B}$ and $W_{N}$ are statistically significant, which supports the estimation of the income equation using the switching regression approach. The results thus suggest that investing in SLM technology is an appropriate alternative for improving farm income among the sampled farmers.

For the Beneficiaries and non-Beneficiaries, the estimated coefficients of the climate change perception were statistically significant. Without adoption of SLM, temperature change perception is associated with lower incomes. With the implementation of SLM, the perception of rainfall change increases farm income by $3.2 \%$ and $2.4 \%$, respectively. For the beneficiary and non-beneficiary farmers, the variables of gender, education and tenure though positive, do not appear to significantly explain farm incomes. Non-beneficiary farms are also seen to rely on household numbers to push farm incomes. However, the parameter for farming experience is significant only in the model for beneficiaries.

Farm size measured as production area, and market access appear to be statistically different for beneficiaries and non-beneficiaries. Each additional hectare increases farm incomes by almost $16 \%$ and $9 \%$, respectively. Market access increases incomes by $6 \%$ and $7 \%$, respectively. Better access to markets and roads is expected to increase the use of purchased inputs and ensure timely delivery of outputs to the market to generate incomes required to ensure the capital intensity of agriculture. However, caution must be exercised since market-driven intensification may also contribute to land degradation by leading to reduced fallowing, which will contribute to declining soil fertility and increased erosion (from reduced vegetative cover) unless sufficiently offset by the adoption of more intensive soil and crop management practices.

As expected, soil or crop management techniques tend to positively influence farm incomes. Socioeconomic choices also exert a positive influence, albeit statistically not significant at conventional levels. Soil and crop management suggests that nutrient gains and erosion control contribute to farm income. Additional access to extension service appears to positively influence farm incomes with the impact on farm incomes pronounced with beneficiary than non-beneficiary farmers. Participation presents positive but small effects in all estimated models, as the partial elasticity for beneficiaries 0.530 , indicating that involvement in the program could increase farm income by $5.3 \%$ and not participating lowers income by $7.5 \%$.

Table 4. Switching regression model of farm revenue (FCFA) for sustainable land management practicing farms

\begin{tabular}{lccccc}
\hline \multirow{2}{*}{\multicolumn{1}{c}{ Parameters }} & \multicolumn{2}{c}{ Beneficiaries } & & \multicolumn{2}{c}{ Non-Beneficiaries } \\
\cline { 2 - 3 } \cline { 5 - 6 } & Coef. & t-stat & & Coef. & t-stat \\
\hline Constant & 3.304 & $2.067^{* *}$ & & 2.682 & $1.721^{*}$ \\
Temperature change perception & 0.252 & $1.679^{*}$ & & 0.316 & 1.361 \\
Rainfall change perception & 0.326 & $1.709^{*}$ & & 0.240 & 1.593 \\
ln Farming Experience & 0.434 & $1.851^{*}$ & & 0.162 & 1.621 \\
ln Household size & 0.359 & 1.525 & & 0.327 & $1.903^{*}$ \\
Gender & 0.243 & 1.046 & & 0.512 & 1.032 \\
Education & 0.236 & 1.312 & & 0.425 & 1.214 \\
Tenure & 0.125 & 1.596 & & 0.511 & 1.245 \\
ln Production Area & 1.617 & $2.263 * *$ & & 0.906 & $1.941^{*}$ \\
Market access & 0.614 & $2.154^{* *}$ & & 0.706 & $1.875^{*}$ \\
North region & 0.311 & 1.377 & & 0.432 & $1.742^{*}$ \\
West region & 0.322 & 1.218 & & 0.328 & 1.351 \\
\hline
\end{tabular}




\begin{tabular}{lcccc}
\hline Adamawa region & 0.421 & 1.453 & 0.376 & 1.631 \\
Soil management adaptation & 0.521 & $1.813^{*}$ & 0.424 & $1.951^{*}$ \\
Crop management adaptation & 0.418 & $1.728^{*}$ & 0.223 & $1.782^{*}$ \\
Socio-cultural adaptation & 0.169 & $1.689^{*}$ & 0.127 & $1.695^{*}$ \\
Adaptation x Temperature change perception & 1.015 & $2.249 * *$ & 0.623 & $1.837^{*}$ \\
Adaptation x Rainfall change perception & 1.376 & $3.018^{* * *}$ & 0.821 & $2.091^{* *}$ \\
Access to extension service & 0.236 & $1.931^{*}$ & 0.114 & 1.523 \\
Participation & 0.530 & $1.824^{*}$ & -0.752 & $-1.794^{*}$ \\
Selectivity terms & 0.458 & $2.272^{* *}$ & 0.321 & $1.936^{*}$ \\
\hline Adjusted R-Sq & & 0.532 & & 0.481 \\
\hline
\end{tabular}

Notes: The dependent variable is natural log of gross farm income (measured in Francs CFA). T-statistic followed by $* * *$ and $* * *$ indicate significance at the $10 \%, 5 \%$ and $1 \%$ level, respectively.

Multiplicative interaction terms are also included to measure the separate impact of the effect of climate change perception on adaptation. The positive coefficients suggest that amongst farmers who perceive climate change whether its changes in rainfall or temperature, are more likely to practice SLM.

Spatial factors represented by the geographical location are also significant for both beneficiary and non-beneficiary of SLM program. The three regions display positive coefficients suggesting that farmers in the selected region have higher levels of income relative to other locations. Specifically, the estimated coefficients of being located in the drier north region of the country are statistically similar between the beneficiary and non-beneficiary equations, suggesting that farmers in the north of the country are more aware of their environmental conditions and employ farm methods to safeguard income levels. In the west region, the coefficients are statistically different suggesting that each group of farmers may require additional information or observation on their environmental experiences. Here, SLM does not significantly affect farm incomes. The identification of perception, experience, markets access and farm size as important constraints unveils the roles such constraints have been noted (e.g. Bryan et al., 2009; Benhin, 2008) to impact on farmers' possibility for adaptation and Nyong et al. (2007) recommendations to better exploit low cost indigenous knowledge to enhance resilience on climate risks and challenges.

The inverse Mill's ratio (selectivity terms) are significant in all the estimations for the beneficiaries and non-beneficiaries. This finding suggests that adoption of SLM technology may have the same effect on the non-beneficiaries if they are included in the program. Furthermore, the significance of the inverse Mill's ratio for SLM beneficiaries indicates that sample selection bias would have resulted if the farm revenue equation had been estimated without taking into account the decision to adopt SLM technology. Overall, these observations are informative on the susceptibility of some farms than others and corroborate Seo et al. (2009), Seo and Mendelsohn (2008) and Benhin (2008) that climate impacts will vary by farms and geography, likely causing economic damage to farmers and possibly to national gross domestic product. In sum, therefore, the promotion of farm techniques and scientific innovations and its eventual adoption depend on the prevailing socioeconomic and political conditions. To promote adaptation and enhance resilience, investment in programs and projects such as the PNDP are potentially important tools for improving agricultural productivity and increasing farmers' incomes. Such policies and programs may attempt to address land management approaches directly, for example, by promoting particular soil fertility management practices.

\section{Conclusion}

This paper has presented empirical evidence that sheds some light on the adoption of SLM as a repertoire of technologies for adaptation to climate change. The results confirm the potential direct role of agricultural technology adoption on improving rural household welfare under climate change perception, as higher incomes from improved technology translate into lower income poverty. A major policy implication of the results is that efforts to encourage farmers to adopt SLM should focus on resource poor smallholder farmers to enhance the nutrient wealth and crop resilience in their farmlands. However, with households that have relatively low levels of education and face land ownership insecurity, extension services and basic education programs are required to support farmers to adopt SLM as a way of adapting to climate change, by providing them with information relating to the positive aspects of land management and building the capacity to understand and successfully 
apply the SLM package. Property rights, access to market, access to extension and farmers' perception of climate change could thus pull farmers in adopting SLM. Adopting SLM is thus a plausible insurance to both climate variability and long-term climate change.

\section{References}

Adesina, A. A., \& Baidu-Forson, J. (1995). Farmers' perceptions and adoption of new agricultural technology: Evidence from analysis in Burkina Faso and Guinea, West Africa. Agricultural Economics, 13, 1-9. http://dx.doi.org/10.1016/0169-5150(95)01142-8

Adesina, A. A., Mbila, D., Nkamleu, G. B., \& Endamana, D. (2000). Econometric analysis of the determinants of adoption of alley farming by farmers in the forest zone of southwest Cameroon. Agriculture, Ecosystems and Environment, 80, 255-265. http://dx.doi.org/10.1016/S0167-8809(00)00152-3

Awudu, A., \& Binder, C. R. (2006). Slash-and-burn cultivation practice and agricultural input demand and output supply. Environment and Development Economics, 11(2), 201-220. http://dx.doi.org/10.1017/S1355770X05002779

Bekele, W. (2005). Stochastic dominance analysis of soil and water conservation in subsistence crop production in the Eastern Ethiopian Highlands: The case of the Hunde-Lafto area. Environmental and Resource Economics, 32, 533-550. http://dx.doi.org/10.1007/s10640-005-0069-2

Benhin, J. K. A. (2008). South African crop farming and climate change: An economic assessment of impacts. Global Environmental Change, 18, 666-678. http://dx.doi.org/10.1016/j.gloenvcha.2008.06.003

Benin, S. (2006). Policies and programs affecting land management practices, input use, and productivity in the highlands of Amhara Region, Ethiopia. In J. Pender, F. Place \& S. Ehui (Eds.), Strategies for Sustainable Land Management in the East African Highlands (pp. 217-256). Washington, DC: IFPRI.

Bryan, E., Deressa, T. T., Gbetibouo, G. A., \& Ringler, C. (2009). Adaptation to climate change in Ethiopia and South Africa: options and constraints. Environmental Science and Policy, 12, 413-426. http://dx.doi.org/10.1016/j.envsci.2008.11.002

FAO (Food and Agricultural Organization of the United Nations). (2009). FAO Strategic Framework 2010-2019. Rome.

Gbetibouo, G. A. (2009). Understanding Farmers' Perceptions and Adaptations to Climate Change and Variability: The Case of the Limpopo Basin, South Africa (IFPRI Discussion Paper 00849). IFPRI, Environment and Production Technology Division, Washington DC.

Gebremedhin, B., Swinton, S. M., \& Tilahun, Y. (1999). Effects of stone terraces on crop yields and farm profitability: Results of on-farm research in Tigray, Northern Ethiopia', Journal of Soil and Water Conservation, 54, 568-573.

Hassan, R., \& Nhemachena, C. (2008). Determinants of African farmers' strategies for adapting to climate change: Multinomial choice analysis. African Journal of Agricultural and Resource Economics, 2(1), 83-104.

Heckman, J. J. (1979). Sample Selection Bias as a Specification Error. Econometrica, 47, 153-162. http://dx.doi.org/10.2307/1912352

Holden, S., Shiferaw, B., \& Pender, J. (2004). Non-farm income, household welfare, and sustainable land management in a less-favoured area in the Ethiopian highlands. Food Policy, 29(4), 369-392. http://dx.doi.org/10.1016/j.foodpol.2004.07.007

Hurni, H. (2000). Assessing sustainable land management (SLM). Agriculture, Ecosystems \& Environment, 81(2), 83-92. http://dx.doi.org/10.1016/S0167-8809(00)00182-1

IPCC (Intergovernmental Panel on Climate Change). (2007). Summary for Policymakers. Climate Change 2007: Impacts, Adaptation and Vulnerability (pp. 7-22). Contribution of Working Group II to the Fourth Assessment Report of the IPCC.

Jaza Folefack, A. J. (2008). The Substitution of Mineral Fertilizers by Compost from Household Waste in Cameroon: Economic Analysis with a Partial Equilibrium Model. Journal of Waste Management \& Research, 26, 1-17.

Jaza Folefack, A. J. (2005). The use of compost from household waste in agriculture: economic and environmental analysis in Cameroon. In W. Doppler \& S. Bauer (Eds.), Farming and Rural Systems 
Economics (Vol. 73, pp. 1-246). Margraf Publishers, Weikersheim, Germany.

Kassie, M., Pender, J., Yesuf, M., Kohlin, G., Bluffstone, R., \& Mulugeta, E. (2008). Estimating returns to soil conservation adoption in the northern Ethiopian highlands. Agricultural Economics, 38(2), $213-232$. http://dx.doi.org/10.1111/j.1574-0862.2007.00295.x

Kurukulasuriya, P., \& Mendelsohn, R. (2008). Crop switching as a strategy for adapting to climate change. African Journal of Agricultural and Resource Economics, 2(1), 105-125.

Lee, L. F. (1982). Some approaches to the correlation of selectivity bias, Review of Economics and Studies, 49, 355-372. http://dx.doi.org/10.2307/2297361

Lutz, E., Pagiola, S., \& Reiche, C. (1994). The Costs and Benefits of Soil Conservation: The Farmer's Viewpoint. The World Bank Research Observer, 9, 273-295. http://dx.doi.org/10.1093/wbro/9.2.273

Maddala, G. S. (1983). Limited Dependent and Qualitative Variables in Econometrics. New York: Cambridge University Press. http://dx.doi.org/10.1017/CBO9780511810176

Maddison, D. (2006). The perception of and adaptation to climate change in Africa (CEEPA Discussion Paper No. 10). Centre for Environmental Economics and Policy in Africa, University of Pretoria, South Africa.

MEA. (2005). Millennium Ecosystem Assessment: Ecosystems and Human Well-being: Synthesis. Washington DC: Island Press.

Mendelsohn, R., Nordhaus, W., \& Shaw, D. (1994). The Impact of Global Warming on Agriculture: a Ricardian analysis. American Economic Review, 84(4), 753-771.

Mertz, O., Mbow, C., Reenberg, A., \& Diouf, A. (2009). Farmers' perceptions of climate change and agricultural adaptation strategies in rural Sahel. Environmental Management, 43, 804-816. http://dx.doi.org/10.1007/s00267-008-9197-0

Molua, E. L. (2011). Farm income, gender differentials and climate risk in Cameroon: typology of male and female adaptation options across agroecologies. Sustainability Science, 6(1), 21-31. http://dx.doi.org/10.1007/s11625-010-0123-z

Molua, E. L., Benhin, J., Kabubo-Mariara, J., Ouedraogo, M., \& El-Marsafawy, S. (2010). Global Climate Change and Vulnerability of African Agriculture: Implications for Resilience and Sustained Productive Capacity. Quarterly Journal of International Agriculture, 49(3), 185-214.

Müller, C., Cramer, W., Hare, W. L., \& Lotze-Campen, H. (2011). Climate change risks for African agriculture. Proceedings of the National Academy of Sciences, 108(11), 4313-4315. http://dx.doi.org/10.1073/pnas.1015078108

Nhemachena, C., Hassan, R., \& Kurukulasuriya, P. (2010). Measuring the Economic Impact of Climate Change on African Agricultural Production Systems. Climate Change Economics, 1(1), 33-55. http://dx.doi.org/10.1142/S2010007810000066

Nyong, A., Adesina, F., \& Osman Elasha, B. (2007). The value of indigenous knowledge in climate change mitigation and adaptation strategies in the African Sahel. Mitigation and adaptation strategies. Global Change, 12, 787-797. http://dx.doi.org/10.1007/s11027-007-9099-0

Pender, J., \& Gebremedhin, B. (2006). Land management, crop production, and household income in the highlands of Tigray, Northern Ethiopia: An econometric analysis. In J. Pender, F. Place \& S. Ehui (Eds.), Strategies for Sustainable Land Management in the East African Highlands (pp. 107-139). Washington, DC: International Food Policy Research Institute.

Pender, J., \& Gebremedhin, B. (2007). Determinants of agricultural and land management practices and impacts on crop production and household income in the highlands of Tigray, Ethiopia. Journal of African Economies, 17, 395-450. http://dx.doi.org/10.1093/jae/ejm028

Pender, J., Ehui, S., \& Place, F. (2006). Conceptual Framework and Hypotheses. In J. Pender, F. Place \& S. Ehui (Eds.), Strategies for Sustainable Land Management in the East African Highlands (pp. 31-58). Washington, DC: International Food Policy Research Institute.

Roudier, P., Sultan, B., Quirion, P., \& Berg, A. (2011). The impact of future climate change on West African crop yields: What does the recent literature say? Global Environmental Change, 21, 1073-1083. http://dx.doi.org/10.1016/j.gloenvcha.2011.04.007

Seo, S. N., \& Mendelsohn, R. (2008). Measuring impacts and adaptations to climate change: a structural 
Ricardian model of African livestock management. Agricultural Economics, 38, 151-165. http://dx.doi.org/10.1111/j.1574-0862.2008.00289.x

Seo, S. N., Mendelsohn, R., Dinar, A., Hassan, R., \& Kurukulasuriya, P. (2009). A Ricardian Analysis of the distribution of climate change impacts on agriculture across agroecological zones in Africa. Environmental Resource Economics, 43, 313-332. http://dx.doi.org/10.1007/s10640-009-9270-z

Schlenker, W., \& Lobell, D. B. (2010). Robust negative impacts of climate change on African agriculture. Environment Research Letters, 5, 1-8. http://dx.doi.org/10.1088/1748-9326/5/1/014010

Shiferaw, B., \& Holden, S. (1998). Resource degradation and adoption of land conservation technologies in the Ethiopian Highlands: A case study in Andit Tid, North Shewa. Agricultural Economics, 18, 233-247. http://dx.doi.org/10.1016/S0169-5150(98)00036-X

Shively, G. E. (1998). Impact of Contour Hedgerows on Maize Yields in the Philippines. Agroforestry Systems, 24(1), 159-168.

Shultz, S., Faustino, J., \& Melgar, D. (1997). Agroforestry and Soil Conservation: Adoption and Profitability in El Salvador. Agroforestry Today, 9, 16-17.

Sleggers, M. F. W. (2008). If only it would rain: Farmers' perceptions of rainfall and drought in semi-arid central Tanzania. Climatic Change, 83, 301-322.

Stern, N. (2006). The Stern Review: the economics of climate change. Cambridge: Cambridge University Press.

Thomas, D., Twyman, C., Osbahr, H., \& Hewitson, B. (2007). Adaptation to climate change and variability: farmer responses to intraseasonal precipitation trends in South Africa. Climatic Change, 83, 301-322. http://dx.doi.org/10.1007/s10584-006-9205-4

Wang, J., Mendelsohn, R., Dinar, A., \& Huang, J. (2010). How Chinese Farmers Change Crop Choice to Adapt To Climate Change. Climate Change Economics, 1(1), 167-185. http://dx.doi.org/10.1142/S2010007810000145

\section{Notes}

Note 1. The agenda of the PNDP (Programme National pour le Développement Participatif) Cameroon's largest World Bank financed CDD project conceived in 2005; is to assist the Government of Cameroon in poverty-alleviation and in enhancing opportunities for growth and employment. Over 1.2 million households covering the ten administrative regions of Cameroon have benefited from the project either directly or indirectly-in terms of rural infrastructure-roads, markets, equipment for classrooms and capacity-building for rural development and country-side enhancements. Under the programme, rural communities elaborate their communal development plans which are then followed-up by the PNDP technical staff providing funding and building the capacity of the benefactors.

\section{Copyrights}

Copyright for this article is retained by the author(s), with first publication rights granted to the journal.

This is an open-access article distributed under the terms and conditions of the Creative Commons Attribution license (http://creativecommons.org/licenses/by/3.0/). 